\title{
FORTHCOMING PAPERS
}

The next issue of the British fournal of Nutrition will appear in June. It is hoped to publish in it the following papers:

A relationship between body fat and plasma pseudo-cholinesterase. By W. T. C. Berry, P. J. Cowin and D. R. Davies.

The nutrition of schoolgirls in Northern Nigeria. By Dagmar C. Wilson.

Goitre in Ceylon and Nigeria. By DAGMar C. Wilson.

The nutrition of male industrial workers with particular reference to intake and expenditure of calories. By E. R. BransBy.

Skeletal depletion in hens laying on a low-calcium diet. By T. G. TAYLOR and J. H. Moore.

Tissue changes in the adult tryptophan-deficient rat. By ANne S. Cole and Patricia P. ScotT.

Serum cholesterol and the diet in clinically healthy men at Slough near London. By ANcel Keys and Margaret H. Keys.

The food intake and energy expenditure of cadets in training. By ELSIE M. WIDDOwsON, O. G. EDHOLM and R. A. MCCANCE.

Malnutrition in African adults. I. Serum proteins, cholinesterase, and protein-bound lipid. By Margaret W. Stai ter and E. G. Holmes.

Myotatic irritability. By V. T. C. BerRY.

The absence of anti-thyroid $\mathrm{p}_{\mathrm{s}}$ ner ies for rats in two types of groundnut oil in common use in Nigeria. By Joyce Buxton, . Tr ary M. Grundy, Dagmar C. Wilson and D. G. Jamison.

Malnutrition in African adults. 2. Protein storage. By E. G. HoLmes, E. R. Jones and Margaret W. Stanier. 


\section{CONTENTS OF VOLUME 8, No. 1, 1954}

\section{(All rights reserved)}

Effects of partial replacement of rice, wheat or ragi (Eleusine coracana) by tuber flours on the nutritive value of poor vegetarian diets. By V. Subrahmanyan, H. B. N. Murthy and M. SWAMinathan

Effects of partial replacement of rice in a rice diet by tapioca flour on the metabolism of nitrogen, calcium and phosphorus in adult human beings. By H. B. N. MurThy, M. SWAminathan and V. Subrahmanyan

Effects on the general health and nutritional status of children of partial replacement of rice in a poor vegetarian diet by tapioca flour. By Saranya Kumari Reddy, T. R. Doraiswamy, A. N. Sankaran, M. Swaminathan and V. Subrahmanyan

Protein katabolism and oxygen consumption during starvation in infants, young adults and old men. By R. A. MCCAnce and W. M. B. Strangeways

Studies of the site of conversion of $\beta$-carotene injected intravenously into rats. By J. G. Bieri and Clifford J. Pollard

Nutritional deficiency and Wallerian degeneration in the rat. I. Effect of protein depletion on the concentration of nucleic acid and phospholipid in intact and sectioned nerves. By W. A. Mannell and R. J. Rossiter

Nutritional deficiency and Wallerian degeneration in the rat. 2. Effect of thiamine deficiency on the concentration of nucleic acid and phospholipid in intact and sectioned nerves. By W. A. Mannell and R. J. Rossiter

The distribution of nicotinic acid in the rice grain. By J. J. C. Hinton and B. SHaw

Some water-soluble vitamins in the sweat of tropically acclimatized European men.

By J. W. H. LugG and F. P. Elitis.

\section{INDEX OF AUTHORS}

\begin{tabular}{|c|c|c|c|}
\hline Bieri, J. G. & 32 & Murthy, H. B. N. & I, II \\
\hline Doraiswamy, T. R. & 17 & Pollard, C. J. & 32 \\
\hline Ellis, F. P. . & 71 & $\begin{array}{l}\text { Reddy, S. K. } \\
\text { Rossiter, R. J. }\end{array}$ & $\begin{array}{r}17 \\
.44,56\end{array}$ \\
\hline Hinton, J. J. C. & 65 & Sankaran A N & \\
\hline Lugg, J. W. H. & $7 \mathrm{I}$ & $\begin{array}{l}\text { Shaw, B. } \\
\text { Strangeways, W. M. B. }\end{array}$ & $\begin{array}{l}11 \\
65 \\
21\end{array}$ \\
\hline $\begin{array}{l}\text { McCance, R. A. } \\
\text { Mannell, W. A. }\end{array}$ & $\begin{array}{r}21 \\
44,56\end{array}$ & $\begin{array}{l}\text { Subrahmanyan, V. } \\
\text { Swaminathan, M. }\end{array}$ & $\begin{array}{l}\mathrm{I}, \mathrm{II}, \mathrm{I7} \\
\mathrm{I}, \mathrm{II}, \mathrm{I} 7\end{array}$ \\
\hline
\end{tabular}

